\title{
Calculating Recommended Fertilizer Rates for Vegetables Grown in Raised-Bed, Mulched Cultural Systems ${ }^{1}$
}

George Hochmuth and Edward Hanlon²

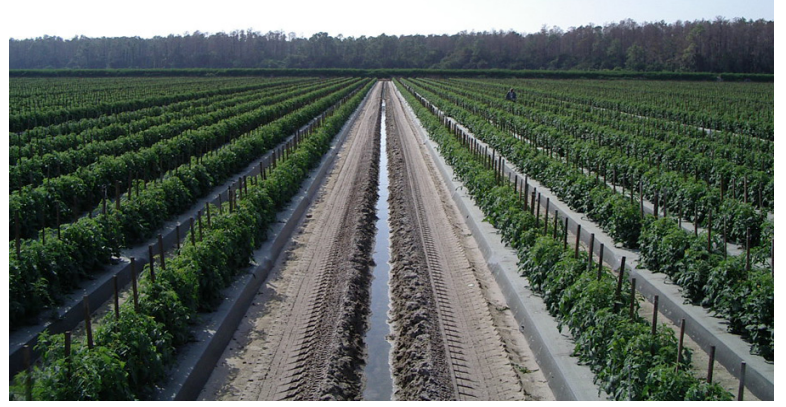

Cover photo. Tomatoes growing in a mulched, raised bed system using a drive-road irrigation/drainage ditch system.

\section{Introduction}

There is increased awareness in Florida about the impact of excess fertilizer nutrients in the environment. The Florida Department of Agriculture and Consumer Services (FDACS) encourages the use of Best Management Practices (BMPs) to minimize the possibility of fertilizer losses from agricultural operations. BMPs are crop production practices that are practical and economical to implement on the farm, which also protect environmental water quality. Many vegetable crops, such as tomato, pepper, eggplant, watermelon, cucumber, strawberry, and others are grown on polyethylene-mulched raised beds. This mulched cultural system typically includes drip irrigation for providing water and fertilizer to the crops; however, for some crops in certain areas in the state, subsurface irrigation systems are still being used to supply water. The mulched system is considered a BMP because it helps protect losses of fertilizer from leaching by rainfall when the fertilizer is placed beneath the mulch. More information on vegetable BMPs can be found at http://www.floridaagwaterpolicy.com/PDF/Bmps/ Bmp_VeggieAgroCrops2005.pdf

Farmers are advised to base their fertilizer rates on Cooperative Extension Service recommendations that are themselves based on many years of research and field demonstration. Extension recommendations embody the Crop Nutrient Requirement (CNR) method. In the CNR approach to fertilization, the fertilizer supplements the nutrient levels already in the soil (and available to the crop) to achieve a

\footnotetext{
1. This document is SL 303, one of a series of the Soil and Water Science Department, Florida Cooperative Extension Service, Institute of Food and Agricultural Sciences, University of Florida. Original publication date July 2009. Visit the EDIS Web Site at http://edis.ifas.ufl.edu.

2. George Hochmuth, professor, Department of Soil and Water Science; Edward Hanlon, professor, Department of Soil and Water Science; Florida

Cooperative Extension Service, Institute of Food and Agricultural Sciences, University of Florida, Gainesville, FL 32611.

All chemicals should be used in accordance with directions on the manufacturer's label.
}

The Institute of Food and Agricultural Sciences (IFAS) is an Equal Opportunity Institution authorized to provide research, educational information and other services only to individuals and institutions that function with non-discrimination with respect to race, creed, color, religion, age, disability, sex, sexual orientation, marital status, national origin, political opinions or affiliations. U.S. Department of Agriculture, Cooperative Extension Service, University of Florida, IFAS, Florida A. \& M. University Cooperative Extension Program, and Boards of County Commissioners Cooperating. Millie Ferrer, Interim Dean. 
positive crop response. Not only is a crop response to fertilization desired, but the fertilizer rate recommendation must also take into account any possible negative impact on the environment, due to leaching or runoff. Certain recommended fertilizer management practices, such as timing, placement, form of fertilizer, etc., also play a role in the environmental aspects of a fertilizer recommendation. Mulching and drip irrigation contribute directly to improving nutrient use by the crop and reduced leaching.

\section{Fertilizer recommendations from UF/IFAS} Extension present the CNRs in terms of the amount of a nutrient needed for the crop. Some growers ask about the "ratio" of nutrients needed in a fertilizer material, such as a $\mathrm{N}: \mathrm{K}$ ratio. A required ratio cannot be proven scientifically because to conduct the study, one needs to change the ratios. In changing the ratio you will necessarily change the rates of one or both of the nutrients. Therefore the rate effect cannot be separated from the ratio effect. Further, once you apply a certain "ratio" to the ground, you lose the ratio because the special ratio fertilizer has now been mixed with the same nutrients already in the soil. The LBF and CNR systems focus on fertilizing the crop, not the soil.

Most public (including Extension) and private soil testing laboratories in the country express fertilizer rates as the amount, e.g., pounds, of a particular nutrient per real estate acre. This rate expression describes an amount (pounds) applied over a surface area (acre), and could be said to be a "fertilize the soil" approach. Today, growers must think more of a "fertilize the crop" approach which the CNR method takes.

\section{What is a fertilizer "recommendation?"}

A fertilizer recommendation is the research-based set of guidelines, or management practices, for supplying fertilizer to the crop to achieve yield and quality goals (economic) of the farmer while doing so in a manner that minimizes nutrient losses to the environment. The amount of a nutrient, e.g., pounds per acre, is only a part of a recommendation. Rate must not be considered alone.
For the rate part of the recommendation to work, the other parts of the recommendation must be included in the overall fertilizer management practice set. Other important parts of a recommendation include:

- Optimum irrigation management so nutrients are not leached or subject to runoff. Irrigation and fertilizer must be managed together to keep the water and nutrients in the root zone;

- Best timing of fertilizer application-matching applications to the crop growth pattern and crop nutrient needs in the season;

- Best placement of fertilizer so it is as close as possible to the roots for absorption;

- Application of fertilizer only when the plants are present and are most likely to absorb the nutrients( e.g., do not apply fertilizer far ahead of crop establishment, unless using a production practice such as mulch to protect the fertilizer from leaching);

- Use of appropriate split applications in the growing season so that fertilizer is more likely to be used by the crop(e. g., split side-dressings, fertigation); and

- Where economical and practical, consideration of fertilizer materials that release nutrients throughout a period of time and are less "soluble", such as controlled-release fertilizers.

Fertilizer BMPs allow the use of seasonal amounts of fertilizer greater than the recommended amount 1) when leaching rains occur, 2) when you have a diagnosed nutrient deficiency, or 3) when you are extending your typical harvesting period due to a continued favorable market.

Usually, application of fertilizer late in the season, or shortly before harvest, does not result in additional yield or quality and is not a part of appropriate fertilizer recommendations. Remember that the nutrient must be taken up by the plant, transferred to the fruit, and incorporated into the fruit/vegetable tissue before late season fertilizer will be of any benefit to the crop. All of this process takes time, and that's why late season or just before harvest 
fertilizer applications are unlikely to improve yield or quality.

\section{The "per acre" expression}

Considering the "per acre" expression in the context of fertilizing the crop growing in a mulched bed system can lead to some confusion. For example, there would be no reason to fertilize the soil in the alleys between mulched beds because there are no vegetable plants growing there. Additional confusion arises in the mulched bed system, because the cropped portion of an acre is often less than the total acre. It is this confusion that this publication addresses. For example, tomato production on one farm using beds spaced 5 feet apart (bed center to bed center) and another farm using beds on 6-foot centers would require the same fertilizer in the row but different total amounts on an acre basis. Another problem arises where a drainage ditch is used between groups of beds, but the area of the acre adjacent to the ditch is not used for crop production. If you provide the same surface-area rate of fertilizer in these examples, then there would be differing amounts of fertilizer applied to the crop because there would be differing amounts of bedded crop in each surface acre of land. There needs to be a method for expressing fertilizer rates that ensures the same crop, growing in differing bed spacing arrangements, will receive the same amount of fertilizer in the root zone. This approach ensures that we fertilize the crop and not the soil. There are examples provided below to illustrate fertilizer calculations in these situations.

The University of Florida Cooperative Extension Service and the Extension Soil Testing Laboratory (ESTL) have chosen to use the "Linear Bed Foot (LBF)" system to further define fertilizer rates for crops grown in mulched-bed culture. The LBF system has been incorporated into the ESTL's Standardized Fertilizer Recommendations System where fertilizer rates are expressed on a per acre basis and LBF. The LBF system automatically standardizes the fertilizer rate applied across varying bed arrangements.

The LBF system can be used to express fertilizer rates for any fertilizer delivery method with mulched beds, including production systems still using the seepage irrigation/fertilization system. Here, a "starter" or "cold" mix (often containing N, P-if needed, and $\mathrm{K}$ ) is incorporated in the soil that forms the bed and the $\mathrm{N}$ and $\mathrm{K}$ fertilizers are placed in narrow grooves in the bed surface. In the production systems that rely on the drip irrigation system to deliver water and fertilizers, the LBF fits closely because growers already know the total length of drip tubing in an acre. In addition, the LBF system can be used for crops such as potato or sweet corn grown in rows without mulch. This publication focuses on the use of the LBF system with crops grown on mulched beds.

\section{Using the LBF system with the IFAS Standardized Fertilizer Recommendations}

\section{Step 1}

The first step is to determine the standardized fertilizer recommendation for the crop of interest. This recommendation will be comprised of two parts: the typical bed spacing (and numbers of rows per bed) for the crop and the rate of fertilizer on a per (real-estate) acre, from the soil testing lab report. The typical bed spacing is that bed spacing that is used by most farmers, and for which much of the fertilization research was conducted. The bed arrangements for several vegetable crops are summarized in Table 1.

\section{Step 2}

Use the information in Step1 to enter Table 2. Using Table 2, go down the left-most column to the row with your crop's typical bed spacing. Go across that row until you come to the column with the recommended fertilizer rate for your crop. The number you find is the amount of fertilizer $\left(\mathrm{N}, \mathrm{P}_{2} \mathrm{O}_{5}\right.$, $\mathrm{K}_{2} \mathrm{O}$ ) you will apply per $100 \mathrm{LBF}$. Divide that number by the \% of $\mathrm{N}, \mathrm{P}_{2} \mathrm{O}_{5}$, or $\mathrm{K}_{2} \mathrm{O}$ in your fertilizer to get the resulting amount of the fertilizer material to apply per $100 \mathrm{LBF}$. If your recommended fertilizer rate is greater than the maximum number in the table (e.g., greater than 180) then select the column with half your recommended rate and double your half-rate answer for the final answer. 


\section{Examples}

\section{Tomato on 6-foot bed centers}

Your nitrogen $(\mathrm{N})$ fertilizer recommendation is 200 pounds per acre. Using Table 2, you would go down the left-most column to the row with 6-foot typical bed spacing. Go across that row until you come to the column with the recommended fertilizer rate of 100 pounds per acre. Come down that column to meet the 6-foot bed spacing row, and find the number 1.38 pounds of $\mathrm{N}$ per $100 \mathrm{LBF}$. You will want to double this amount because we used the 100 pound column and your recommended rate was 200 pounds per acre. So you will need to apply 2.76 pounds of N per $100 \mathrm{LBF}$. You can check your math by noting that there are $72.6100-\mathrm{LBF}$ in an acre of beds on 6 -foot centers (Table 1). Then you will note than 72.6 times 2.76 equals 200 .

If your fertilizer is $25 \% \mathrm{~N}$ then you will apply 11.04 pounds of fertilizer per $100 \mathrm{LBF}$. This calculation is $2.76 / 0.25=11.04$. Please keep in mind this is the amount for the seasonal CNR and you might be planning on split-applications or applying in weekly amounts through the drip irrigation system.

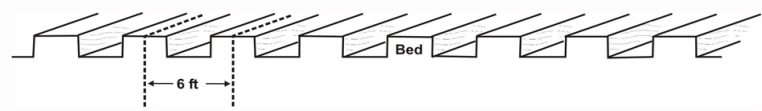

Fig. 1. Uniform bed spacing pattern across a field.

\section{Tomato on 5-foot centers}

Your nitrogen $(\mathrm{N})$ fertilizer recommendation is 200 pounds per acre. Using Table 2, proceed down the left-most column to the row with 6-foot typical bed spacing. Go across that row until you come to the column with the recommended fertilizer rate of 100 pounds per acre. Come down that column to meet the 6-foot bed spacing row, and find the number 1.38 pounds of N per $100 \mathrm{LBF}$. You will want to double this amount because we used the 100 pound column and your recommended rate was 200 pounds per acre. So you will need to apply 2.76 pounds of $N$ per 100 LBF. If your fertilizer is $25 \% \mathrm{~N}$ then you will apply 11.04 pounds of fertilizer per $100 \mathrm{LBF}$.

This is the same answer you saw in example 1. Why? Remember our objective is to standardize our fertilizer rate under the mulched bed and to "fertilize the crop." Both examples use tomato as the crop. Example 1 fits exactly the typical bed arrangement. The farmer in example 2 has a higher plant density (more rows) in a real-estate acre by using beds on 5 -foot centers. The goal is the same fertilizer rate per $100 \mathrm{LBF}$, but since the farmer in example 2 has more LBF of beds, there will be a corresponding increase in the total amount of fertilizer per real-estate acre, but the same rate per $100 \mathrm{LBF}$, which is the goal of the fertilization program, to fertilize the crop.

The fertilizer for Farmer 1 works out to be 200 lbs/acre because he is growing tomatoes on the typical bed spacing of 6 feet. The fertilizer rate for Farmer 2 works out to be $240 \mathrm{lbs} /$ acre because she is growing tomatoes on 5 - $\mathrm{ft}$ centers. Both are using the research-developed recommended rate per 100 LBF/acre. Farmer 2 has more plants per acre; therefore needs more fertilizer per acre, but each plant has been supplied the same amount of nutrition in both cases.

\section{Tomatoes on 6-foot centers with a 12-ft wide ditch/access road every 6 beds}

In this example, neither the crop, bed spacing, nor fertilizer rate has changed. The bed spacing is 6-feet and the recommended $\mathrm{N}$ rate is still 200 pounds per acre. Therefore the recommended $\mathrm{N}$ rate is still 2.76 pounds per $100 \mathrm{LBF}$. The difference in this example compared with the examples discussed above is the loss of cropped area to the ditches and access roads. The cropped area is $75 \%$ of the real-estate acre. The farmer will apply the same rate of $\mathrm{N}$ under the mulch, which is our goal, to fertilize the crop, but will purchase less fertilizer for the real-estate acre compared with examples 1 or 2 . Example 3 is the more typical situation, with ditches or drive roads, compared to examples 1 or 2 (also, please see the cover photo). There may be production systems that result in cropped areas different from $75 \%$, but the same calculation principles hold.

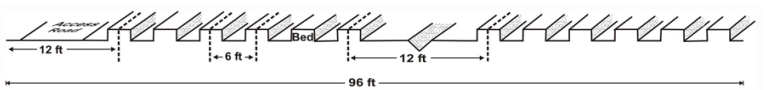

Fig. 2. Bed spacing pattern of 6 -foot bed centers depicting either a 12-foot wide ditch/road or access road every 6 beds. 


\section{Watermelons on 8-foot centers with a 12-ft drive road every 5 beds}

The recommended $\mathrm{N}$ rate for watermelon is 150 pounds per acre for the typical bed spacing of 8 feet (Figure 3). From Tables 1 and 2, you must read down the 100 pound per acre column until you come to the 8 -foot spacing row in Table 2. You will get 1.84 pounds per $100 \mathrm{LBF}$. Since the recommendation is 150 pounds per acre, you need to add $50 \%$ more to 1.84 , and will get 2.76 pounds per $100 \mathrm{LBF}$. You also could have interpolated between the columns for 140 and 160 pounds per acre. If your fertilizer contains $25 \% \mathrm{~N}$, then you apply 11.04 pounds of fertilizer per $100 \mathrm{LBF}$. If you grew watermelons on 9-ft. beds, then you would use the same fertilizer rate per $100 \mathrm{LBF}$, but you would need a little less fertilizer per real estate acre.

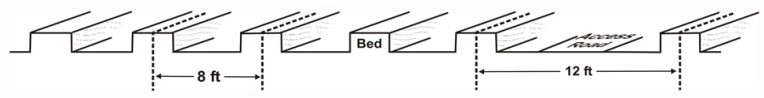

Fig. 3. An example of five 8-foot beds plus one 8-foot drive road.

\section{Summary}

Growers need to fertilize the crop and not the soil; therefore you are interested in applying the fertilizer in a manner that is consistent with maximized crop use. The linear bed foot (LBF) system allows you to standardize the amounts of fertilizer for the crop even if you are growing crops in varying bed spacing among farmers. This publication explains the LBF concept and provides easy-to-use tables for converting a fertilizer recommendation from pounds per acre to pounds per $100 \mathrm{LBF}$. Examples are provided to illustrate the concept in several situations in Florida vegetables.

\section{Definitions of terms:}

Real-estate acre: Farm land (land area) that occupies 43,560 square feet. This term also may be called "gross acre" and refers to the land area used for crop production, including the cropped land plus the land used for access roads and irrigation/drainage ditches.

Cropped area: The portion of the real-estate acre used solely for crop production. Alternatively, the cropped area is the land remaining after uncropped land, such as access roads, and irrigation/drainage ditches have been subtracted from the real-estate area. If the entire area is used for crop production, then the cropped area is equal to the real-estate area. Otherwise the cropped area is less than the real-estate area.

Recommended fertilizer rate: This is the amount of fertilizer determined by field research to be needed for normal and economical crop production. This amount will satisfy the crop needs for the season under good growing conditions: where leaching rain does not occur, or where other problems do not limit the plant's access to nutrients. Consistent with the BMPs, a grower might end up using more than the recommended rates, for example when tissue tests indicate a low nutrient level, when there is a leaching rain event, or when the harvesting season will be extended due to favorable prices.

Linear bed foot (LBF): The LBF is the linear distance of 1 foot measured along a raised, mulched bed. The total number of LBF in a particular planting system or bed arrangement system that is the cropped area of real-estate acre is expressed as the LBF per acre (LBF/acre). For simplicity, it is preferred to express the rate per $100 \mathrm{LBF}$ per acre. Growers easily adapt to the LBF system for expressing fertilizer rates because they already know how many linear feet of plastic mulch and drip tubing they use per real estate acre. Also, a similar linear foot system is used to calibrate their fertilizer spreading equipment. 
Table 1. Typical bed spacing and number of rows per bed for some vegetable crops grown in mulched bed culture.

\begin{tabular}{|l|c|c|c|l|c|c|c|}
\hline Vegetable crop & $\begin{array}{c}\text { Typical bed } \\
\text { spacing (ft) }\end{array}$ & $\begin{array}{c}\text { No. of } \\
\text { 100- LBF } \\
\text { per acre }\end{array}$ & $\begin{array}{c}\text { Number of } \\
\text { rows of } \\
\text { plants on a } \\
\text { bed }\end{array}$ & Vegetable crop & $\begin{array}{c}\text { Typical bed } \\
\text { spacing (ft) }\end{array}$ & $\begin{array}{c}\text { No. of } \\
\text { 100- LBF } \\
\text { per acre }\end{array}$ & $\begin{array}{c}\text { Number of } \\
\text { rows of } \\
\text { plants on a } \\
\text { bed }\end{array}$ \\
\hline Broccoli & 6 & 72.6 & 2 & Muskmelon & 5 & 87.1 & 1 \\
\hline Cabbage & 6 & 72.6 & 2 & Pepper & 6 & 72.6 & 2 \\
\hline Cauliflower & 6 & 72.6 & 2 & Squash-summer & 6 & 72.6 & 2 \\
\hline Cucumber & 6 & 72.6 & 2 & Squash-winter & 6 & 72.6 & 2 \\
\hline Eggplant & 6 & 72.6 & 1 & Strawberry & 4 & 108.9 & 2 \\
\hline Lettuce & 4 & 108.9 & 2 & Tomato & 6 & 72.6 & 1 \\
\hline Leafy greens & 6 & 72.6 & 2 & Watermelon & 8 & 72.6 & 1 \\
\hline
\end{tabular}

${ }^{\mathrm{z}}$ The bed spacing is measured from the center of one bed to the center of the adjacent bed.

Table 2. Conversion of fertilizer rates in pounds per acre to pounds per $100 \mathrm{LBF}^{2}$.

\begin{tabular}{|c|c|c|c|c|c|c|c|c|c|}
\hline \multirow{3}{*}{$\begin{array}{l}\text { Typical } \\
\text { bed } \\
\text { spacing } \\
\text { (ft) }\end{array}$} & \multicolumn{9}{|c|}{$\begin{array}{l}\text { Recommended fertilizer rate }\left(\mathrm{N}, \mathrm{P}_{2} \mathrm{O}_{5}, \mathrm{~K}_{2} \mathrm{O}\right) \\
\text { (pounds per acre) }\end{array}$} \\
\hline & 20 & 40 & 60 & 80 & 100 & 120 & 140 & 160 & 180 \\
\hline & \multicolumn{9}{|c|}{$\begin{array}{l}\text { Resulting fertilizer rate }\left(\mathrm{N}, \mathrm{P}_{2} \mathrm{O}_{5}, \mathrm{~K}_{2} \mathrm{O} \text { ) }\right. \\
\text { (pounds per } 100 \mathrm{LBF} \text { ) }\end{array}$} \\
\hline 3 & 0.14 & 0.28 & 0.41 & 0.55 & 0.69 & 0.83 & 0.96 & 1.10 & 1.24 \\
\hline 4 & 0.18 & 0.37 & 0.55 & 0.73 & 0.92 & 1.10 & 1.29 & 1.47 & 1.65 \\
\hline 5 & 0.23 & 0.46 & 0.69 & 0.92 & 1.15 & 1.38 & 1.61 & 1.84 & 2.07 \\
\hline 6 & 0.28 & 0.55 & 0.83 & 1.10 & 1.38 & 1.65 & 1.93 & 2.20 & 2.48 \\
\hline 8 & 0.37 & 0.73 & 1.10 & 1.47 & 1.84 & 2.20 & 2.57 & 2.94 & 3.31 \\
\hline
\end{tabular}

${ }^{\mathrm{z}}$ This table is used correctly by (1) determining the typical bed spacing from Table 1 for the crop; (2) locating the column containing the recommended fertilizer rate in pounds per acre; and (3) reading down the column until reaching the row containing the typical bed spacing. The resulting number in pounds per $100 \mathrm{LBF}$ should be used even in situations where the farmers bed spacing differs from the typical bed spacing. Use of the table will involve doubling the rate, for example where the column for 100 pounds per acre was used in the calculation of pounds per $100 \mathrm{LBF}$ for a recommended rate of 200 pounds per acre. 